\title{
Evaluation of the Application of Health and Safety Management System (SMK3) in the Mining Company of PTX. Based on Government Regulation Number 50 of 2012
}

\author{
Suhartina Suhartina ${ }^{1}$, Lalu M. Saleh ${ }^{1 *}$, Syaifuddin Sirajuddin ${ }^{2}$, Sumbangan Baja $^{3}$, Anwar Mallongi $^{4}$ \\ ${ }^{1}$ Department of Occupational Health and Safety, Faculty of Public Health, Hasanuddin University, Makassar, Indonesia; \\ ${ }^{2}$ Department of Nutrition, Faculty of Public Health, Hasanuddin University, Makassar, Indonesia; ${ }^{3}$ Department of Soil Science \\ Faculty of Agriculture, Hasanuddin University, Makassar, Indonesia; ${ }^{4}$ Department of Environmental Health, Faculty of Public \\ Health, Hasanuddin University, Makassar, Indonesia
}

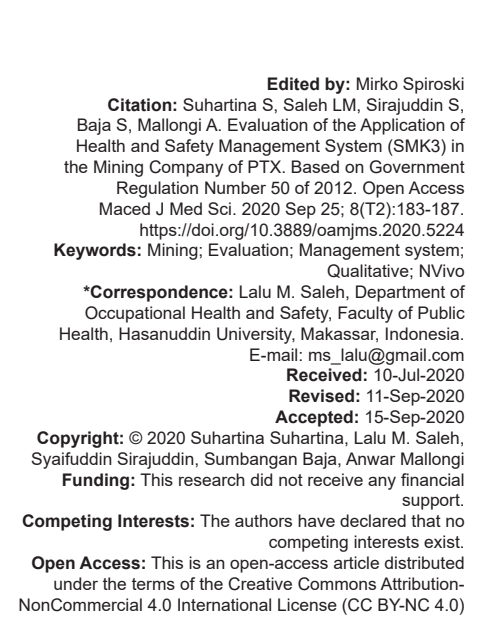

\section{Introduction}

The mining industry sector has high potential risks in the process. The number of accidents that occur both in the oil and gas mining sector, as well as the mineral and coal mining sector such as fire, blasting, environmental pollution, and others [1]. Mining operations currently generally carry out their activities by appointing contractor/subcontractor companies which are stated in the mining regulations as a company that has a mining service business permit (IUJP). PT $X$ is one of the IUJP owner companies listed in the directorate general of minerals and coal. The role of the contractor is vital for the mining industry, especially in supporting operational activities. Contractors are directly involved in the implementation of work so that they are more directly exposed to hazards when carrying out work activities than company personnel so that contractor workers are more prone to work accidents [1].

Circular of the directorate general of minerals and coal (mineral and coal) as of July 30, 2018, mentioned, in the period January to July 2018, there were 86 work accidents, in which 38 accidents resulting in serious injuries, 38 minor injuries, and ten fatalities (fatality). Of the 86 accidents, $47.50 \%$ occurred in the contractor, $15.00 \%$ occurred in the subcontractor, and $37.50 \%$ in the owner. The high number of accidents that occur requires contractors and subcontractors to be able to carry out work safely in terms of occupational health and safety. Hence, in this case, each contractor or subcontractor is required to apply a work safety and health management system in accordance with applicable laws and standards, because the performance of the contractor can affect the company's performance both that affects the HSE, productivity, and image of a company [2]. 
Research conducted by Messah [3] on construction service companies in Kupang City, stated that the ten provisions most widely applied by construction service companies are establishing OHS policies $(86.84 \%)$, identifying hazards that will occur $(84.21 \%)$, provide funds for the implementation of K3 $(84.21 \%)$, determine accident risk control $(81.58 \%)$, regulations based on legislation on K3 $(81.58 \%)$, provide sufficient amount of P3K facilities $(81.58 \%)$, making goals and objectives to be achieved (78.95\%), and each party involved in the construction service company must play a role in maintaining and controlling the implementation of $\mathrm{K} 3(76.32 \%)$, there is a division of tasks and responsibilities clear $(73.68 \%)$ and implementation of controls to manage $\mathrm{K} 3$ hazards $(73.68 \%)$ [3].

Law number 13 of 2003 and government regulation number 50 of 2012, companies that employ 100 employees and or $<100$ people but who have high risk potential are required to implement an occupational safety and health management system (SMK3).

PT $X$ have 454 employees, based on this reference, $\mathrm{PT} X$ has implemented a work safety and health management system since 2015 and received recognition in the form of a certificate from the Ministry of Manpower of the Republic of Indonesia, butPTXaccident data in 2018 occurred 10 times with work accidents. This research aims to evaluating the application of occupational safety and health management systems to contractors in the management area of PT Sims Jaya Kaltim based on government regulation number 50 of 2012.

\section{Materials and Methods}

This research was conducted at PT. X, located in Paser Regency, East Kalimantan, from May to July 2019. The research used was an evaluation research and evaluation model of Stake countenance by dividing into three stages, namely, antecedents, transaction, and outcomes [4].

The selection of research informants was carried out by purposive sampling with the research informants being those who had the authority, knowledge and were directly involved in the application of Occupational Safety and Health at PT. PT X, namely: The person in charge of the occupational safety and health system in the HSE Department and the Supervisors of each department, who have worked for more than 1 year and understand the system.

Data collection is done by in-depth interviews, observation, and document review. Records of the results of field observation interviews and document review obtained conformity assessments based on the number of criteria in appendix 11 of government regulation number 50 of 2012 (appropriate or not appropriate), then entered into the following formula:

$$
\begin{gathered}
\% \text { of Result }=\frac{\sum \text { Overall criteria }-}{\sum \text { non }- \text { conforming criteria }} \\
\left.\sum \text { Overall criteria }\right)
\end{gathered}
$$

Evaluation of evaluation results:

1. $0-59 \%$ in the bad implementation level category

2. $60-84 \%$ in the good application level category

3. $85-100 \%$ in the satisfactory application level category.

The results of the in-depth interview were processed using the NVivo. NVivo Application is a computer application program used to help researchers manage and analyze data. NVIVO was developed by QSR International.

\section{Results}

This study involved six respondents from each department. There are two elements of an occupational safety and health management system in the antecedents stage, namely, the policy and leadership element and the planning element. Table 1 triangulation of sources for policy elements obtained a value of $53 \%$ with less categories, for the planning elements in Table 2, the results of triangulation obtained the source value obtained $57 \%$ including the less category.

Table 1: Element triangulation of policy and planning in the mining company

\begin{tabular}{llll}
\hline Element & Triangulation & PT X & Results \\
\hline Policy & Interview & SPY & $53 \%$ \\
Planning & Review the document & Manual Level I & $57 \%$ \\
elements & Observation Criteria & IJA-SOP-HSE-01 & \\
& Interview & IJA-SOP-HSE-02a & \\
& Review the document & IJA-SOP-HSE-02b & \\
& Observation Criteria & IJA-SOP-HSE-02c & \\
& & There are 26 criteria, 14 criteria & \\
& accordingly and 12 criteria do not match & \\
& SPY & \\
& Manual Level I \\
& IJA-SOP-HSE-14 \\
& IJA-SOP-HSE-02a & \\
& IJA-SOP-HSE-02b \\
& IJA-SOP-HSE-02c \\
& IJA-SOP-HSE-008 \\
& There are 14 criteria, 14 criteria are & \\
& suitable and 6 criteria are not suitable \\
\hline
\end{tabular}

The implementation of occupational safety and health management system in the transaction stage consists of ten elements it showed at Table 2 with, namely: (1) Source triangulation for control elements and contract design is $100 \%$ obtained, (2) source triangulation for document control elements obtained a value of $100 \%$, (3) source triangulation for 
Table 2: Element triangulation of process at The Mining Company

\begin{tabular}{|c|c|c|c|}
\hline Element & Triangulation & PTX & Results \\
\hline Contract control and design & Interview & SPY & $100 \%$ \\
\hline Document control & Review the document & IMK & $71.4 \%$ \\
\hline Purchasing and Product Control Elements & Observation Criteria & IJA-SOP-HSE-14 & $100 \%$ \\
\hline Working Safety Elements Based on SMK3 & Interview & There are eight criteria and all criteria are suitable & $100 \%$ \\
\hline Monitoring standard & Review the document & SPY & $100 \%$ \\
\hline Reporting and improvement & observation criteria & IJA-SOP-HSE-14 & $100 \%$ \\
\hline Material Management and Displacement & Interview & There are seven criteria, five criteria are suitable, and two criteria are not & $100 \%$ \\
\hline Data Collection and Management & Review the document & suitable & $100 \%$ \\
\hline Observation Criteria SMK3 Examination & Observation Criteria & SPY, YSR & 0 \\
\hline \multirow[t]{42}{*}{ Skills and Ability Development } & Interview & IJA-SOP-PURC-14 & $92,8 \%$ \\
\hline & Review the document & IJA-SOP-LOG-02 & \\
\hline & Observation Criteria & There are seven criteria and all criteria are suitable & \\
\hline & Interview & ED, SPY & \\
\hline & Review the document & IJA-SOP-HSE-12 & \\
\hline & Observation Criteria & IJA-SOP-HSE-13 & \\
\hline & Interview & IJA-SOP-HSE-16 & \\
\hline & Review the document & IJA-SOP-HSE-18 & \\
\hline & Observation Criteria & IJA-SOP-HSE-19 & \\
\hline & Interview & There are 41 criteria and all criteria are suitable & \\
\hline & Review the document & YSR & \\
\hline & Observation Criteria & IJA-SOP-HSE-06 & \\
\hline & Interview & IJA-SOP-HSE-10 & \\
\hline & Review the document & IJA-SOP-HSE-34 & \\
\hline & Observation Criteria & IJA-SOP-HSE-19 & \\
\hline & Interview & There are 17 criteria and all criteria accordingly & \\
\hline & Review the document & SPY & \\
\hline & Observation Criteria & IJA-SOP-HSE-18 & \\
\hline & Interview & IJA-SOP-HSE-18 & \\
\hline & Review the document & IJA-SOP-HSE-09 & \\
\hline & Observation Criteria & There are nine criteria and all & \\
\hline & & $\begin{array}{l}\text { criteria accordingly } \\
\text { YSR }\end{array}$ & \\
\hline & & IJA-SOP-HSE-14 & \\
\hline & & IJA-SOP-PURC-01 & \\
\hline & & IJA-SOP-HSE-10 & \\
\hline & & IJA-SOP-HSE-15 & \\
\hline & & IJA-SOP-HSE-12 & \\
\hline & & IJA-SOP-LOG-05 & \\
\hline & & IJA-SOP-LOG-16 & \\
\hline & & IJA-SOP-LOG-17 & \\
\hline & & There are 12 criteria and all criteria accordingly & \\
\hline & & SPY & \\
\hline & & IJA-SOP-HSE-07 & \\
\hline & & There are six criteria and all criteria are suitable & \\
\hline & & SPY & \\
\hline & & IJA-SOP-HSE-27 & \\
\hline & & There are no appropriate criteria & \\
\hline & & SPY & \\
\hline & & IJA-SOP-HSE-03 & \\
\hline & & IJA-SOP-HRD-03 & \\
\hline & & IJA-SOP-HRD-03 & \\
\hline & & There are 14 criteria, 13 criteria are suitable, and one criteria are not & \\
\hline
\end{tabular}

purchasing elements and product control obtained $100 \%$ value, (4) source triangulation for Work Safety Element Based on SMK3 obtained 100\% value, (5) triangulation the Monitoring Standards element is rated $100 \%$, (6) triangulation source element reporting and improvement is obtained $100 \%$, (7) triangulation source material management elements and its displacement is obtained $100 \%$ value , (8) triangulation of sources the data collection and management elements are obtained $100 \%$, (9) triangulation of sources of SMK3 examination elements obtained a value of 0 no criteria met, and (10) source triangulation the Skills and Capability Development Element based on the triangulation of sources was $92 \%$.

Outcomes phase is the value obtained from the results of the calculation of the antecedents stage and the results of the calculation of the antecedents stage obtained a value of $70.5 \%$.

\section{Discussion}

In this stage, there are two elements, namely, policy and value planning obtained the second stage of $\mathrm{PT} X$, has made a K3 policy in writing, dated, the contents include $\mathrm{K} 3$ goals and objectives as well as a written statement of commitment, but do not yet have evidence in the form of minutes of meetings related to policy formulation or policy revision, this is not in accordance with government regulation number 50 of 2012 article seven states that companies in setting policies must pay attention to input from workers, laborers or workers' associations. At PT $X$ also has not yet renewed the organization of the Committee for Safety and Occupational Health as the implementation of K3 in the workplace.

Policy on the main requirements of the management system occupational safety and 
health policy is an embodiment of the top leadership commitment which contains the vision and goals of the organization, commitment and determination to implement occupational health and safety, work frameworks, and programs [1]. In line with the Research Zulyanti [5], it is suggested that the K3 Management System is a pattern of applying K3 MPS KUD Tani Mulyo policy which is part of the overall management system of the company. The weakness of the management system has a large role as a cause of accidents, because the management system is what governs the elements of production.

PT $X$ in planning based on the results of risk management according to risk management procedures in the form of hazard identification and risk control (HIRC), which refers to the statutory regulations only the personnel who carry out the HIRC have resigned but the documents have not been revised.

Failure to implement an occupational safety and health management system can be caused because the HIRC process is not carried out properly and comprehensively. The results of the implementation of HIRC are the main inputs in preparing the work plan. PT $X$ has not conducted routine reporting on $\mathrm{P} 2 \mathrm{~K} 3$ activities in contrast to research conducted by Gemely [6] at PT. Pelindo IV (Persero) Makassar Container Terminal P2K3 activities and programs follow the rules and regulations, namely, the obligation to report quarterly with regard to $\mathrm{OSH}$ to the local labor department and annual reports to the central office for evaluation. OHS Program and implementation are delegated to the P2K3 secretary who makes quarterly and annual reports to PT. Pelindo IV (Persero) Makassar Container Terminal.

PT $X$ made a documentation system using a documentation system hierarchy which was arranged into four levels, namely, level 1 for manuals, level 2 for SOPs, level 3 for work instructions/JSA, and level 4 forms. According to Ramli [1], to facilitate the documentation of the occupational health and safety system, a hierarchical $\mathrm{OSH}$ document system is used by dividing 4 (four) levels. In line with the research of Yuliani [7] document control at PT Angkasa Pura II (Persero) Bandung is carried out with maintenance and structuring of SMK3 related documents as well as procedures for making and approving documents as well as for handling obsolete documents, recording and management information about the Management and Work Safety System.

PT $X$ conducts hazard monitoring through a five-minute talk (P5M) activity discussing K3 information, both inspection and third hazard report. There are various ways to report unsafe conditions or potential hazards, for example, through workplace inspection results, hazards observation. Prasetyo published that the K3 Inspection Program as an effort to promote OHS Culture in the work environment has been seen from an increase in awareness of the importance of $\mathrm{K} 3$ in the work environment and Evaluation of accident trend data continues to decline [8].
In the implementation of P5M, inspection and hazard report is a monitoring so that workers can work with AMA, in line with Research by Wuon [9] where the application of SMK3 in companies that have been carried out in protecting the safety of workers is in the form of procurement of a number of Personal Protective Equipment as a preventative technical effort work accident. In the study of Zulyanti [5] MPS KUUD TaniMulyo as a commitment to the availability of resources, machinery and facilities used have been certified for the proper use. MPS KUD Tani Mulyo also provided support in the form of providing funds for the completion of the K3 annual work program.

Health monitoring is also carried out by $\mathrm{PT} X$ by routinely measuring the work environment in collaboration with the hyperkes center, in line with research conducted by Eksis [10] at the Central Post Office in Samarinda City. Through direct measurements, data on temperature and humidity are obtained. Indoor air is $31.110 \mathrm{C}$ and humidity $65.5 \% \mathrm{RH}$, this value is outside the provisions of the PUSPERKES standard, the level of lighting in the waiting room is obtained 105.5 Lux data, this data show that the existing lighting level is in accordance with international standards, the assessment of the room noise level is $75.23 \mathrm{~dB}$, which means this room is at a standard.

PT.X in the case of handling materials/materials in the design of storage materials/materials that differ between hazardous and toxic materials and materials that do not contain hazardous and toxic materials, in accordance with Government Regulation Number 50 Year 2012 article 11 paragraph two letter a mentioned, entrepreneurs in carrying out the occupational health and safety plan to take control measures [11].

In line with research conducted by Ratman [12], B3 waste management of PT. Toyota Motor Manufacturing Indonesia adheres to national regulations in Indonesia that have been regulated by KLH through PP. no. 18 of 1999 and PP No. 85 of 1999 and supported by other regulations. B3 waste generated by $\mathrm{PT}$. Toyota Motor Manufacturing Indonesia is IPAL sludge, sludge painting, phosphate sludge, used thinner, used oil, used battery, used waste, used TL lights, used B3 packaging (paint cans, jerry cans, thinner cans, and drums), incinerator ash, and polyclinic waste.

According to Government Regulation number 50 of 2012 article one, SMK3 audit is a systematic examination and the fulfillment of established criteria to measure the results of activities planned and implemented in implementing SMK3 in a company, where PT X's audit has not conducted an audit based on government regulations. In the other research by Istiqlal [13] that the antecedents step are stages of K3 policy and planning determination to SMK3 implementation, the second is transaction with the K3 planning stage gets the appropriate category according to SMK3 and implementation get a category that is not appropriate, and then the output is the stages of $\mathrm{K} 3$ monitoring and evaluation get an inappropriate and improvement $\mathrm{K} 3$ performance and the 
last is the factors influencing the application of K3, namely, supporting factors are documentation; P3K; suitable work environment; objectives and programs implemented; and inhibiting factors are OHS commitment and supervision as well as the non-functioning of specific organizations.

PT Iwaco itself is made a matrix training according to the needs per year. The HRD Department through the training section compiled the matrix. While in the research Zulyanti [5] suggested that the elements of training and competency led the MPS KUD TaniMulyo employees toward competent human resources in the Occupational Health and Safetyfield. MPS KUD TaniMulyo is committed to providing competent resources to achieve the goal of applying Occupational Health and Safetypolicy. This is proven the company conducts training to develop its human resources in the field of occupational health and safety both internally conducted by the company itself and externally from PT. HM Sampoerna or with related institutions and competent actors. While in Andriyanto research [14] suggested that employees be given training related to occupational health and safety.

\section{Recommendation}

The application of the management system at $\mathrm{PT} X$ should be made in an integrated manner so that the documentation system is easy and also as the basis for implementing the management system. PT $X$ must also form a P2K3 organization based on legal regulations.

\section{References}

1. Ramli SR. OHSAS 18001 Occupational Health and Safety Management System. Jakarta: Dian Rakyat; 2014

2. Minerba. Mining Performance Improvement Warning. Jakarta:
Direktorat Jenderal Mineral dan Batubara; 2018.

3. Messah YA, Yohana BT. Implementation, SMK3, Construction Service Companies. J Teknik Sipil. 2012;1(4):101-14.

4. Arikunto S, Jabar CS, Cepi SA. Evaluation of Educational Programs: Practical Theoretical Guidelines for Students and Practitioners of Education. Jakarta Timur: PT Bumi Aksara; 2010.

5. Zulyanti N. Komitmen Kebijakan K3 sebagai upaya perlindungan terhadap tenaga kerja (Studi pada mitra produksi sigaret (MPS) KUD tani mulyo lamongan). J Adm Publik Desember. 2013;11(2):264-75

6. Gemely D, Russeng S, Jafar N. Implementation of safety management system and makassar container terminal in 2018 Makassar container terminal in 2018. J Kesehatan Masyarakat Unhas. 2018;1(2):201-14. https://doi.org/10.30597/jkmm. v1i3.8729

7. Yuliani N, Ekawati, Bina K. Analisis pendokumentasian sistem manajemen keselamatan dan kesehatan kerja berdasarkan PP No. 50 tahun 2012 di PT angkasa pura II (persero) Bandung. J Kesehatan Masyarakat FKM UNDIP. 2015;3(3):545-54. https:// doi.org/10.30597/jkmm.v1i3.8729

8. Prasetyo E, Endah RB. Analisis program inspeksi keselamatandan kesehatan kerja (K3) sebagai bentuk upaya promosi budaya K3 di lingkungan kerja. J Stikes Cendikia Utama. 2016;4(1):1-8. https://doi.org/10.31227/osf.io/qaznb

9. Wuon AB. Analisis penerapan sistem manajemen keselamatan dan kesehatan kerja di PT kerismas witikco makmur bitung. J Unstrat. 2013;1(1):1-22. https://doi.org/10.38165/jk.v8i1.94

10. Eksis J. Measurement of the physical environment of work and workstations at the samarinda central post office. Pos Pusat Samarinda. 2011;7(2):1931-8.

11. Peraturan Pemerintah Republik Indonesia. Peraturan Pemerintah Nomor 50 Tahun 2012. Jakarta: Presiden Republik Indonesia; 2012. https://doi.org/10.21107/ri.v12i1.2925

12. Ratman $\mathrm{CY}$, Syafrudin $\mathrm{S}$. Penerapan pengelolaan limbah $B 3$ di PT. Toyota motor manufacturing Indonesia. JPRESIPITASI. 2010;7(1):62-70.

13. Istiqlal KR, Ketut II. Evaluasi penerapan sistem manajemen kselamatan dan kesehatan kerja (K3) berdasarkan sistem manajemen K3 (SMK3). J Pendidikan Teknik Elektro. 2017;7(2):152-60. https://doi.org/10.31219/osf.io/8v4ke

14. Andriyanto $M$. Hubungan predisposing factor dengan perilaku penggunaan APD pada pekerja unit produksi I PT. Petrokimia Gresik. Universitas Airlangga. Indones J Occup Saf Health. 2017;6(1):37-47. https://doi.org/10.20473/ijosh.v6i1.2017.37-47 